\title{
Development of a simplified RT-PCR without RNA isolation for rapid detection of RNA viruses in a single small brown planthopper (Laodelphax striatellus Fallén)
}

\author{
Qiufang Xu' ${ }^{1}$, Haoqiu Liu', Pingping Yuan ${ }^{1,2}$, Xiaoxia Zhang ${ }^{1}$, Qingqing Chen ${ }^{1}$, Xuanli Jiang $^{2}$ and Yijun Zhou ${ }^{1 *}$
}

\begin{abstract}
Background: The small brown planthopper (SBPH) is an important pest of cereal crops and acts as a transmission vector for multiple RNA viruses. Rapid diagnosis of virus in the vector is crucial for efficient forecast and control of viral disease. Reverse transcription polymerase chain reaction (RT-PCR) is a rapid, sensitive and reliable method for virus detection. The traditional RT-PCR contains a RNA isolation step and is widely used for virus detection in insect. However, using the traditional RT-PCR for detecting RNA virus in individual SBPHs becomes challenging because of the expensive reagents and laborious procedure associated with RNA isolation when processing a large number of samples.

Results: We established a simplified RT-PCR method without RNA isolation for RNA virus detection in a single SBPH. This method is achieved by grinding a single SBPH in sterile water and using the crude extract directly as the template for RT-PCR. The crude extract containing the virus RNA can be prepared in approximately two minutes. Rice stripe virus (RSV), rice black streaked dwarf virus (RBSDV) and Himetobi P virus (HiPV) were successfully detected using this simplified method. The detection results were validated by sequencing and dot immunobinding assay, indicating that this simplified method is reliable for detecting different viruses in insects. The evaluation of the sensitivity of this method showed that both RSV and HiPV can be detected when the CDNA from the crude extract was diluted up to $10^{3}$ fold. Compared to the traditional RT-PCR with RNA isolation, the simplified RT-PCR method greatly reduces the sample processing time, decreases the detection cost, and improves the efficiency by avoiding RNA isolation.
\end{abstract}

Conclusions: A simplified RT-PCR method is developed for rapid detection of RNA virus in a single SBPH without the laborious RNA isolation step. It offers a convenient alternative to the traditional RT-PCR method.

Keywords: Small brown planthopper, Virus detection, Simplified RT-PCR

\section{Background}

The small brown planthopper (SBPH), Laodelphax striatellus Fallén (Delphacidae: Hemiptera), is a serious sapsucking pest of agricultural crops. More importantly, it acts as an insect vector to transmit multiple plant viruses and causes severe yield losses. For example, it transmits reoviruses (RBSDV and maize rough dwarf virus) [1, 2], tenuiviruses (rice stripe virus, RSV) [3], rhabdoviruses (barley yellow striate mosaic virus and northern cereal

\footnotetext{
* Correspondence: yjzhou@jaas.ac.cn

${ }^{1}$ Institute of Plant Protection; Jiangsu Academy of Agricultural Sciences; Jiangsu Technical Service Center of Diagnosis and Detection for Plant Virus Diseases, Nanjing, Jiangsu, People's Republic of China

Full list of author information is available at the end of the article
}

mosaic virus) $[4,5]$, and cripaviruses (Himetobi $\mathrm{P}$ virus, HiPV) [6]. Both RSV and RBSDV are transmitted by SBPH in a persistent, circulative and propagative manner. RSV can be transmitted by SBPH from mother to offspring [7], while RBSDV cannot. The rice stripe disease caused by RSV damaged over 957,000 hectares of paddy fields in 2003 and 1,571,000 hectares in 2004, accounting for 80\% of the rice fields and a $30-40 \%$ yield loss in China [8]. RBSDV not only infects rice plants to cause rice blackstreaked dwarf disease, but also causes maize rough dwarf disease in maize [1]. These viral diseases have been economically destructive in the rice- and maize- growing areas in China for decades [9]. 
Rapid diagnosis of virus in vector is important for viral disease forecast and control. Various approaches have been developed for detection of RNA virus in its insect vector, including biological inoculation $[10,11]$, direct observation using electron microscopes [3, 12], antibody-based serological method [13], and other molecular detection methods. Biological inoculation method is time consuming and labor-intensive; for example, it takes approximately one month for the plants to show disease symptoms after inoculation with RBSDV via viruliferous insects [11]. Electron microscopes are very expensive and require specialtytrained personnel to operate them. In addition, the results of electron microscopy usually need to be confirmed by other methods [12]. Serological methods, such as enzymelinked immunosorbent assay, are economical for detection of high throughput samples [14], but they are limited by the specificity and availability of antibodies against the virus. Deep sequencing and qRT-PCR and are of high sensitivity and specificity [15-17], but expensive. RT-PCR is a rapid, specific and reliable assay to detect RNA viruses $[18,19]$, especially for viruses that do not have antibodies available.

Traditional RT-PCR assays usually require purified RNA for reverse transcription. Isolation of RNA with commercial kits is expensive and time consuming. Besides, as $\mathrm{SBPH}$ is a small insect, measuring approximately $2-4 \mathrm{~mm}$ long, it is challenging to purify RNA from an individual SBPH. In this study, we developed a simplified RT-PCR assay for RNA virus detection in a single SBPH without RNA isolation. The sensitivity and reliability of this detection method are assessed and compared with those of traditional RT-PCR.

\section{Methods}

\section{Preparation of SBPH used for virus detection}

SBPHs free of RSV and RBSDV has been continuously maintained in our lab over ten years. A RSV-viruliferous SBPH population, with a RSV infection rate higher than $80 \%$, was screened and reared in the lab on rice seedlings grown in $1 \mathrm{~L}$ beakers at $25{ }^{\circ} \mathrm{C}$ with a photoperiod of $16 \mathrm{~h} / 8 \mathrm{~h}$ (light/dark).

The RBSDV-infected SBPH vectors were prepared as described previously [20]. Non-viruliferous SBPHs were fed with rice black streaked dwarf diseased plants for three days, and then transferred to healthy rice seedlings for two weeks to pass the latent period. The SBPHs were subsequently collected for RBSDV detection. RSV-free and RSV-viruliferous SBPHs in 2nd to 4th instar were mixed and used for HiPV detection and duplex RT-PCR assay.

\section{Crude extract preparation from a single SBPH for reverse transcription}

The SBPHs reared on rice seedlings were collected and frozen in $-20{ }^{\circ} \mathrm{C}$ for $5 \mathrm{~min}$. A single SBPH was placed in a $0.2 \mathrm{~mL}$ centrifuge tube, washed with $100 \mu \mathrm{L}$ sterile $\mathrm{H}_{2} \mathrm{O}$, and ground with sterile wet toothpicks in $30 \mu \mathrm{L}$ sterile $\mathrm{H}_{2} \mathrm{O}$. After centrifugation at $12,000 \mathrm{~g}$ for $1 \mathrm{~min}$, the supernatant from individual $\mathrm{SBPH}$ was immediately transferred to new $200 \mu \mathrm{L}$ centrifuge tube and used for reverse transcription.

\section{RT-PCR}

The crude RNA extract was used as template for simplified RT-PCR. The cDNA was synthesized using M-MuLV 1st strand cDNA synthesis kit (Sangon Biotech, P.R. China) according to the manufacturer's protocol. The procedure is as followed: $11 \mu \mathrm{L}$ crude sample and $1 \mu \mathrm{L}$ random primer (Random $6,0.2 \mu \mathrm{g} / \mu \mathrm{L}$ ) were mixed and incubated at $65{ }^{\circ} \mathrm{C}$ for $5 \mathrm{~min}$, the mixture then was transferred onto ice for $30 \mathrm{~s}$ immediately. After a short centrifuge, $4 \mu \mathrm{L} 5 \times \mathrm{M}$-MuLV reverse transcriptase buffer, $2 \mu \mathrm{L}$ dNTP mix $(10 \mathrm{mM}), 1 \mu \mathrm{L}$ RNase inhibitor $(20 \mathrm{U} / \mu \mathrm{L})$ and $1 \mu \mathrm{L}$ M-MuLV RT $(200 \mathrm{U} / \mu \mathrm{L})$ were added. The tubes were incubated in $25{ }^{\circ} \mathrm{C}$ for $10 \mathrm{~min}$, $42{ }^{\circ} \mathrm{C}$ for $1 \mathrm{~h}$, and $70{ }^{\circ} \mathrm{C}$ for $10 \mathrm{~min}$. The resulting cDNA could be stored in $-20{ }^{\circ} \mathrm{C}$ or applied to virus PCR detection directly.

Specific virus primers were used for PCR amplification to detect viruses in a single SBPH (Table 1). PCRs were performed with a final reaction volume of $20 \mu \mathrm{L}$, containing $5 \mu \mathrm{L}$ cDNA, $10 \mu \mathrm{L} 2 \times$ Taq Master Mix (Vazyme Biotech, P.R. China), $0.5 \mu \mathrm{L}$ each of the primers. The initial denaturation $\left(95{ }^{\circ} \mathrm{C}, 5 \mathrm{~min}\right)$ was followed by 40 cycles of $95{ }^{\circ} \mathrm{C}$ for $30 \mathrm{~s}, 58{ }^{\circ} \mathrm{C}$ for $30 \mathrm{~s}, 72{ }^{\circ} \mathrm{C}$ for $1 \mathrm{~min}$, and a final extension step at $72{ }^{\circ} \mathrm{C}$ for $10 \mathrm{~min}$. A plasmid containing the RSV CP gene was used as PCR positive control for detection of RSV and a plasmid with the RBSDV P10 gene for RBSDV. Crude extracts from non-viruliferous SBPH were used as negative controls. The PCR products were evaluated by agarose gel electrophoresis.

Table 1 Primers used for RT-PCR or qRT-PCR amplification of RSV, RBSDV and HiPV

\begin{tabular}{llll}
\hline Name & Sequences $\left(5^{\prime} \rightarrow 3^{\prime}\right)$ & $\begin{array}{l}\text { Accession } \\
\text { number }\end{array}$ & $\begin{array}{l}\text { Amplicon } \\
\text { length }(\mathrm{bp})\end{array}$ \\
\hline RSV CP-F1 & ATGGGTACCAACAAGCCAGC & EF198700 & 936 \\
RSV CP-R1 & CTAGTCATCTGCACCTTCTG & & \\
RBSDV P10-F & ATGGCTGACATAAGACTCGA & NC_003733 & 1677 \\
RBSDV P10-R & TCATCTTGTCACTTTGTTA & & \\
HiPV-F & CTGGACAACATGATATTAGA & AB183472 & 678 \\
HiPV-R & CTATTCCCAGTTCCAAG & & \\
RSV CP-F2 & GCCACTCTAGCTGATTTGA & EF198700 & 167 \\
RSV CP-R2 & GTGTCACCACCTTTGTCCTT & & \\
\hline
\end{tabular}




\section{Dot immunobinding assay (DIBA)}

Crude extracts $(1 \mu \mathrm{L})$ were dotted individually onto a nitrocellulose membrane $(0.2 \mu \mathrm{m}$ pore size, Pall $)$ and allowed to dry at room temperature. Nonspecific sites were blocked with blocking buffer containing $2 \%$ skim milk in PBST $\left(137 \mathrm{mM} \mathrm{NaCl}, 2 \mathrm{mM} \mathrm{KCl}, 10 \mathrm{mM} \mathrm{Na} 2 \mathrm{HPO}_{4}\right.$, $2 \mathrm{mM} \mathrm{KH} \mathrm{PO}_{4}, \mathrm{pH} 7.5,0.05 \%$ Tween-20) at $37{ }^{\circ} \mathrm{C}$ for $30 \mathrm{~min}$. The membrane was subsequently incubated in blocking buffer containing RSV- or RBSDV-specific monoclonal antibody at $1: 5,000$ dilution at $37{ }^{\circ} \mathrm{C}$ for $1.5 \mathrm{~h}$. After wash for three times (each $5 \mathrm{~min}$ ) with PBST, membranes were immersed in secondary antibody conjugated with HRP (Sigma-Aldrich, USA) at 1:2,000 dilution with PBST containing $2 \%$ skim milk. After another round of washes ( 3 times), the membranes were developed in a freshly prepared substrate solution containing $6 \mathrm{mg}$ 4-chloro-1-naphtol, $2 \mathrm{~mL}$ ethanol, and $7 \mu \mathrm{L}$ of $30 \%$ $\mathrm{H}_{2} \mathrm{O}_{2}$ in $10 \mathrm{~mL}$ PBS. The crude extracts of the individual SBPHs that developed well-defined dots and those with no dots on the membranes were kept in $-20^{\circ} \mathrm{C}$, and used as positive and negative controls for the DIBA assay.

\section{Comparison of sensitivity of virus detection with and without RNA isolation}

To compare the detection sensitivities of the simplified RT-PCR using crude extract and the traditional RT-PCR using purified RNA, RSV RNA in individual SBPHs was prepared by these two methods and detected using RSV $\mathrm{CP}$ primers. Individual SBPHs were ground as described above. An aliquot of $11 \mu \mathrm{L}$ supernatant was immediately transferred to a new tube for centrifugation and then the crude extract was used for reverse transcription. Another aliquot of $11 \mu \mathrm{L}$ supernatant was used for Trizol RNA isolation. The reverse transcribed products were evaluated by PCR and qRT-PCR.

As SBPHs cannot be completely ground by toothpick, the tissue in the same volume of the supernatant $(11 \mu \mathrm{L})$ may not be equal. In order to ensure that the two methods processed the same amount of tissue sample, the RSV-viruliferous SBPHs were treated in another way. Every 10 SBPHs at the third instar stage were collected in a $1.5 \mathrm{~mL}$ centrifuge tube and ground in liquid nitrogen using a pestle. Then $100 \mu \mathrm{L}$ RNase-free $\mathrm{ddH}_{2} \mathrm{O}$ were added. After thorough vortexing, $11 \mu \mathrm{L}$ suspensions was transferred to a new tube as crude extract and another $11 \mu \mathrm{L}$ suspension was used for Trizol RNA isolation.

\section{Trizol RNA isolation}

Isolation of total RNAs with Trizol (Invitrogen, USA) was operated according to the manufacturer's protocol with some modifications. An aliquot of $11 \mu \mathrm{L}$ of supernatant was transferred to a new $1.5 \mathrm{~mL}$ tube. Subsequently $120 \mu \mathrm{L}$ Trizol and $26 \mu \mathrm{L}$ chloroform were added and mixed well. After centrifugation of the tube at $12,000 \mathrm{~g}$ for
15 min at $4{ }^{\circ} \mathrm{C}$, the upper aqueous phase was immediately transferred into a new $1.5 \mathrm{~mL}$ Eppendorf tube. An equal volume of isopropanol was added to the aqueous layer, vortexed and placed in room temperature for $10 \mathrm{~min}$. After centrifugation at $12,000 \mathrm{~g}$ for $10 \mathrm{~min}$ at $4{ }^{\circ} \mathrm{C}$, the supernatant was removed and the RNA pellet was rinsed with $200 \mu \mathrm{L}$ 75\% ethanol twice. The RNA was dried and resuspended in $11 \mu \mathrm{L}$ RNase-free $d_{d H_{2}} \mathrm{O}$. The total RNA was used for reverse transcription or stored at $-70{ }^{\circ} \mathrm{C}$.

\section{qRT-PCR}

qRT-PCR was performed with an IQ5 Real-Time PCR System (Bio-Rad, USA) in a final reaction volume of

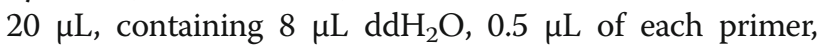
$1 \mu \mathrm{L}$ of cDNA template and $10 \mu \mathrm{L}$ of $2 \times$ SYBR@premix Ex Taq II (Tli Rnase H plus) (TaKaRa, including SYBR Green I, TaKaRa Ex Taq HS, dNTP mixture, $\mathrm{Mg}^{2+}$ and Tli RnaseH). The PCR was run as described previously [20].

\section{Results \\ The simplified RT-PCR method detected RSV in single SBPHs}

The simplified RT-PCR was used to amplify the RSV CP gene in the RSV-viruliferous SBPH. The designed primers specifically amplified a fragment of $936 \mathrm{bp}$, which is consistent with the expected size (Fig. 1a). The PCR products were further confirmed to be the RSV CP gene (Additional file 1) by sequencing. The results indicated that RSV was successfully detected by the simplified RT-PCR. To confirm the results, the crude extracts from individual SBPHs were also processed by DIBA assay using RSV monoclonal antibody. As shown in Fig. 1b, the results of DIBA assay are consistent with those of RT-PCR.

\section{The simplified RT-PCR method detected RBSDV in single SBPHs}

In addition to detection of RSV in individual SBPHs, we also detected RBSDV using the simplified RT-PCR method without RNA isolation. The specific fragments with expected size of $1,677 \mathrm{bp}$ were obtained in positive samples and confirmed to be the RBSDV P10 gene by sequencing (Additional file 1); no bands were amplified in the non-viruliferous SBPH samples (Fig. 2a), indicating that RT-PCR using crude extract successfully detected RBSDV in a single SBPH. The results were further validated by DIBA using RBSDV monoclonal antibody (Fig. 2b). The data confirmed that this simplified RT-PCR method was reliable for detecting RNA virus in SBPH.

\section{HiPV was detected in single SBPHs}

HiPV was found in SBPH in early 1990s [6, 21] and its existence was confirmed by high-throughput sequencing [17]. We used the RT-PCR method without RNA 


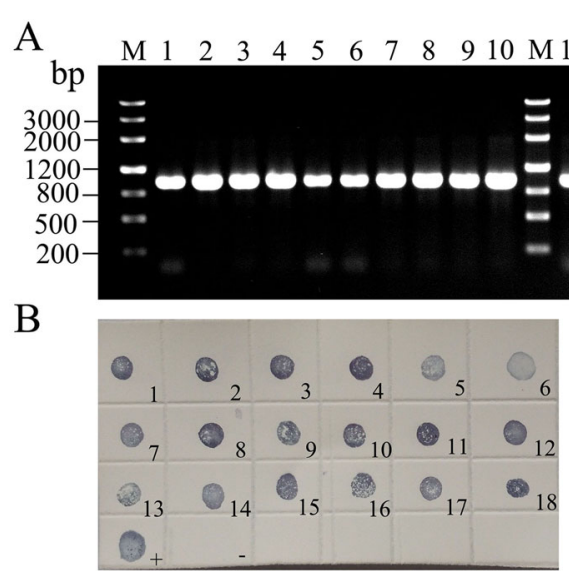

Fig. 1 RSV detection in individual SBPHs. a PCR results of the RSV detection using the simplified RT-PCR; (b) RSV detection by DIBA assay

isolation to analyze whether HiPV existed in our laboratory-reared SBPH. The results showed that the specific bands with expected size of 678 bp were successfully amplified in HiPV-infected SBPHs (Fig. 3). Sequencing results revealed that the PCR products were specific to the corresponding virus (Additional file 1), which validated the specificity and reliability of the assay.

\section{Duplex RT-PCR simultaneously detected two RNA viruses} in single SBPHs

To test whether the cDNA prepared from crude extract could be used for simultaneous detection of multiple RNA viruses, duplex RT-PCRs were performed to amplify RSV and HiPV in a single SBPH. The primer pairs for the two viruses were mixed and used for virus detection. A $678 \mathrm{bp}$ PCR product corresponding to RSV or a $936 \mathrm{bp}$ corresponding to HiPV was detected in SBPHs infected only by RSV or HiPV; the samples infected with both viruses detected both fragments of $678 \mathrm{bp}$ and $936 \mathrm{bp}$ (Fig. 4).

\section{Analytical sensitivity of the simplified RT-PCR}

To evaluate the relative sensitivity of this method, a series of 10 -fold dilutions of the cDNA obtained from crude extracts were used for PCR analysis. Consistent with the different accumulation in individual SBPHs (shown in Figs. 1, 2 and 3), the detection sensitivity varies in different virus species. RSV and HiPV could be detected up to $10^{3}$ fold dilution, although the HiPV specific band was not distinct at $10^{3}$ fold dilution. RBSDV could be detected by the presence of an expected PCR product when the crude extracts were diluted 10 fold (Fig. 5).

\section{Comparison of the sensitivity of RT-PCR with or without the RNA isolation step}

To compare the detection sensitivity of the simplified RT-PCR and traditional RT-PCR, single RSV-viruliferous SBPHs were ground and RSV in the same volume of the crude suspension was detected by these two methods. The RSV CP gene could be detected in all the five independent samples by both methods (Fig. 6a). RSV abundance was measured by scanning the gray value of the

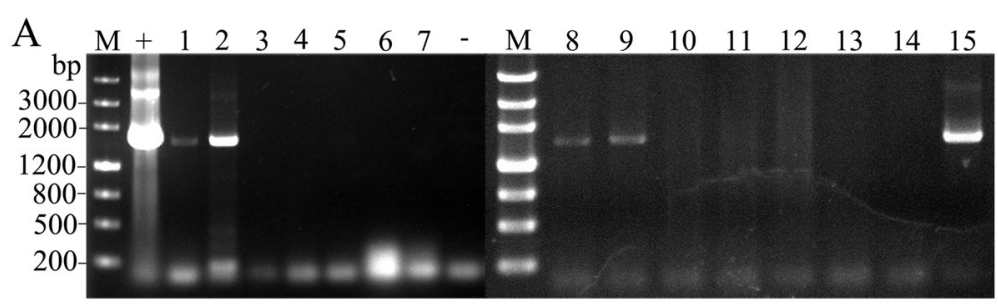

B

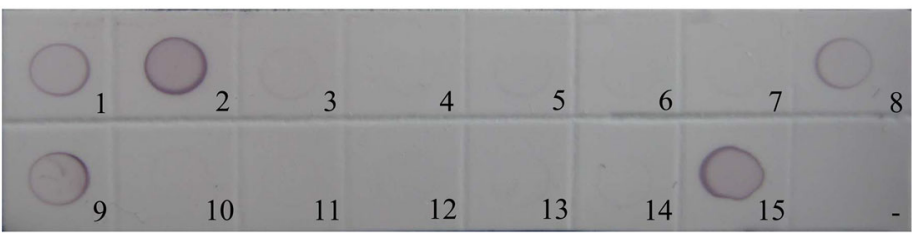

Fig. 2 RBSDV detection in individual SBPHs. a PCR results of the RBSDV detection using the simplified RT-PCR; (b) Detection of RBSDV by DIBA assay 


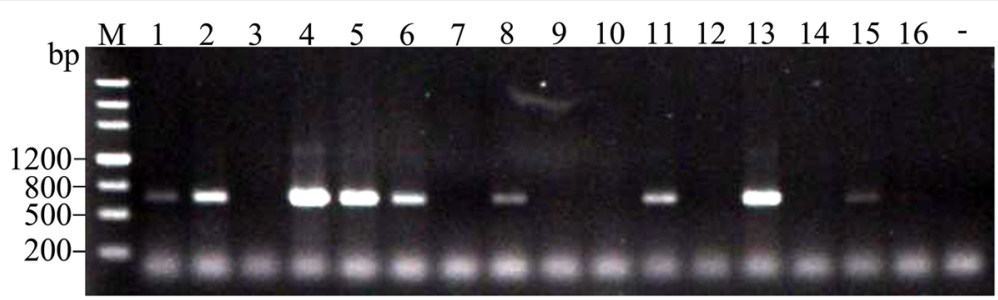

Fig. 3 Detection of HiPV in single SBPHs using the simplified RT-PCR

PCR bands. The ratio of the gray values of PCR product amplified from Trizol extracted RNA and crude samples (Trizol/crude) was close to 1.0 (Fig. 6b), indicating that there are no obviously differences in the detection sensitivities between the simplified RT-PCR and traditional RT-PCR.

To more accurately evaluate the detection sensitivities of these two detection methods, we used qRT-PCR to compare the RSV abundance in the samples prepared by the two methods. The RSV abundance in the samples was evaluated by the CT value of qRT-PCR. The virus abundance in the crude samples was set as the reference, and the relative virus abundance in the samples prepared by traditional Trizol extraction (Trizol/Crude) was calculated by $2^{\triangle \mathrm{CT}(\mathrm{Crude}-\mathrm{Trizol})}$. The results showed that the viral RNA abundance in samples \#6 and \#8 extracted using Trizol were higher than those in crude extracts, while sample \#7 showed the opposite result (Fig. 6c). We speculated the reason was that the SBPH was not crushed completely by toothpick and thus the tissues could not be divided evenly.

In order to avoid this problem, we further ground 10 $\mathrm{SBPHs}$ in nitrogen liquid and distributed equal amount of tissues for further processing by the two different methods; samples \#9, \#10, and \#11 represent this preparation. The qRT-PCR results show that the relative RSV abundance in the samples using Trizol isolation contains an average RSV level seven fold over those prepared using the simplified method (Fig. 6d).

Monitoring the ratio of viruliferous SBPH in the field insect population is important for viral disease forecasting and control. To test whether the simplified RT-PCR could be used for field insect samples, we collected field insect samples from Kaifeng, Henan Province, China for RBSDV detection. Ninety six SBPHs were randomly selected to detect RBSDV using the traditional RT-PCR method and the simplified RT-PCR established in this study. A single $\mathrm{SBPH}$ was ground in $30 \mu \mathrm{L}$ sterile $\mathrm{H}_{2} \mathrm{O}$. After centrifugation, $11 \mu \mathrm{L}$ supernatant was used for detection by the simplified RT-PCR and the rest of the sample by traditional RT-PCR. The results obtained by the two methods are consistent; both methods showed that three samples were RBSDV positive (Additional file 2: Figure S1), suggesting that the simplified RT-PCR is reliable for detecting virus in field insect samples.

\section{Discussion}

Plants are infected by a wide range of viruses that cause economic losses and pose threats to certain agricultural industries. Hemipteran insects act as the main vectors for the plant viruses, transmitting as much as $55 \%$ of the described plant viruses. Planthoppers in Hemiptera mainly transmit RNA viruses: among the 18 viruses they transmit, 14 are RNA viruses [22]. Analysis of virus infection in the insect vector is important for preventing the potential disease threat. In this study, we developed a simplified RT-PCR method without RNA isolation for RNA virus detection in a single SBPH. The virus RNA preparation can be completed in approximately $2 \mathrm{~min}$ and requires no pre-treatments for RNA purification. This simplified method may be expanded for detection of RNA viruses in other insects in Hemiptera with similar insect size, such as aphids, leafhoppers, brown planthopper and whitebacked planthopper.

The traditional RT-PCR for RNA virus detection contains a laborious RNA isolation process [18]. There are several methods to isolate RNA from insects, including using commercial SV total RNA isolation system (Promega) [23], Trizol reagent (Invitrogen) [24], and the RNAiso Reagent (TaKaRa) [15]. The RNA samples isolated by these

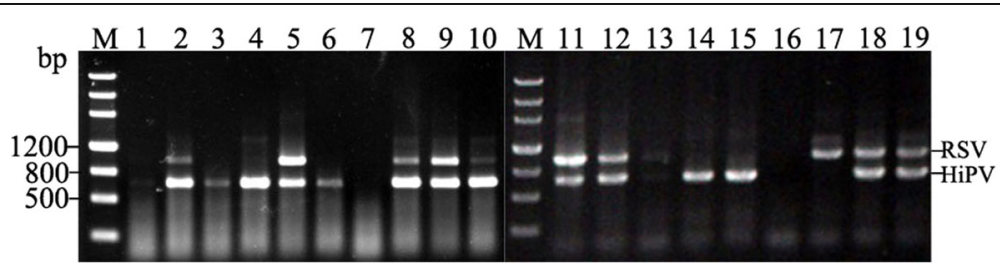

Fig. 4 Simultaneous detection of HiPV and RSV by duplex RT-PCR without RNA isolation 


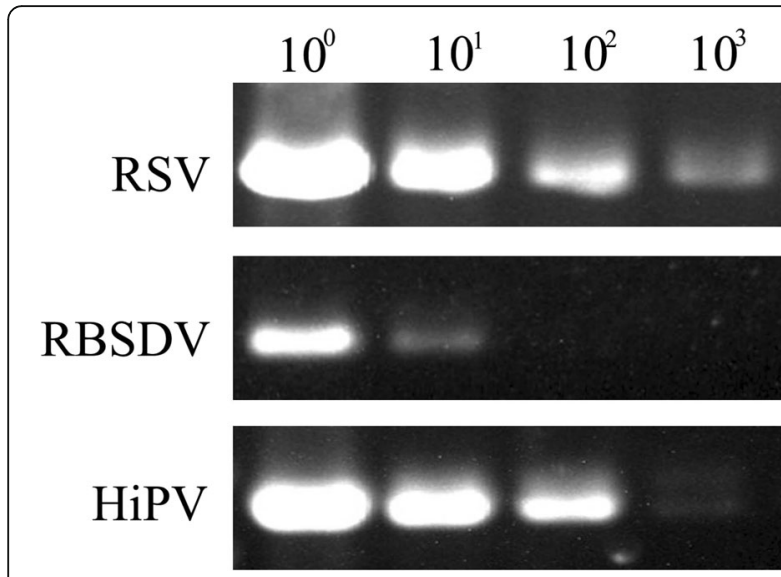

Fig. 5 Detection of RSV, RBSDV and HiPV by simplified RT-PCR in a 10-fold serial dilution

methods are of high quality with limited contamination and can produce well-defined amplification products in RT-PCR [25]. However, it is expensive to use these commercial kits. Besides, it is time-consuming and inconvenient to extract RNA from a single SBPH because planthoppers are of small size. Our method offers an effective way to detect viruses in a large number of planthopper samples by eliminating the expensive and laborious RNA isolation process.

The quality of RNA is considered as one of the important factors that affect the accuracy of RT-PCR. RNA samples with their A260/A280 ratios falling between 1.8-2.0 are considered to be of good quality and selected for RT-PCR and subsequent analysis [26]. The A260/ A280 ratios of crude extracts of SBPH in our assay are below 1.8 (data not show) and the crude extracts are presumed to contain contaminating components, such as DNA, protein and lipid, which might inhibit RT-PCR reactions. However, the simplified RT-PCR successfully detected the RSV, RBSDV and HiPV in SBPH (Figs. 1, 2 and 3 ). Moreover, the cDNA prepared by the described protocol can be used for duplex RT-PCR and qRT-PCR for virus detection (Figs. 4, Fig. 6c and d). These results suggest that the contaminants in crude extracts do not affect the detection results, which is in agreement with previous studies showing that viruses could be detected specifically in plant samples by RT-PCR using unpurified RNA [27]. One possible explanation is that the contaminants in planthopper extracts that can inhibit RT-PCR reactions are present at very low concentrations, not high enough to cause problems in RT-PCR.

On the other hand, we found that the reverse transcription method affects the result of the simplified RT-PCR. When we first incubated the crude extract at $65{ }^{\circ} \mathrm{C}$ with random primer (Random 6) and then proceeded to reverse transcription as described in the Methods, the RNA virus was successfully detected (Figs. 1, 2 and 3). However, when the cDNA was obtained by using the primeScript $^{\text {tix }}$ RT Master Mix (Takara, contains every components except the RNA template for reverse transcription) without heat treatment, the RNA virus could not be detected by the simplified RT-PCR. We hypothesize that virus particles in $\mathrm{SBPH}$ may require heat disruption at $65{ }^{\circ} \mathrm{C}$ to release RNA for cDNA synthesis. Alternatively, contaminating inhibitors may be inactivated by treatment at $65^{\circ} \mathrm{C}$.

The sensitivity of the detection method is another important factor for virus detection. Our results show that the simplified RT-PCR method bears the sensitivity
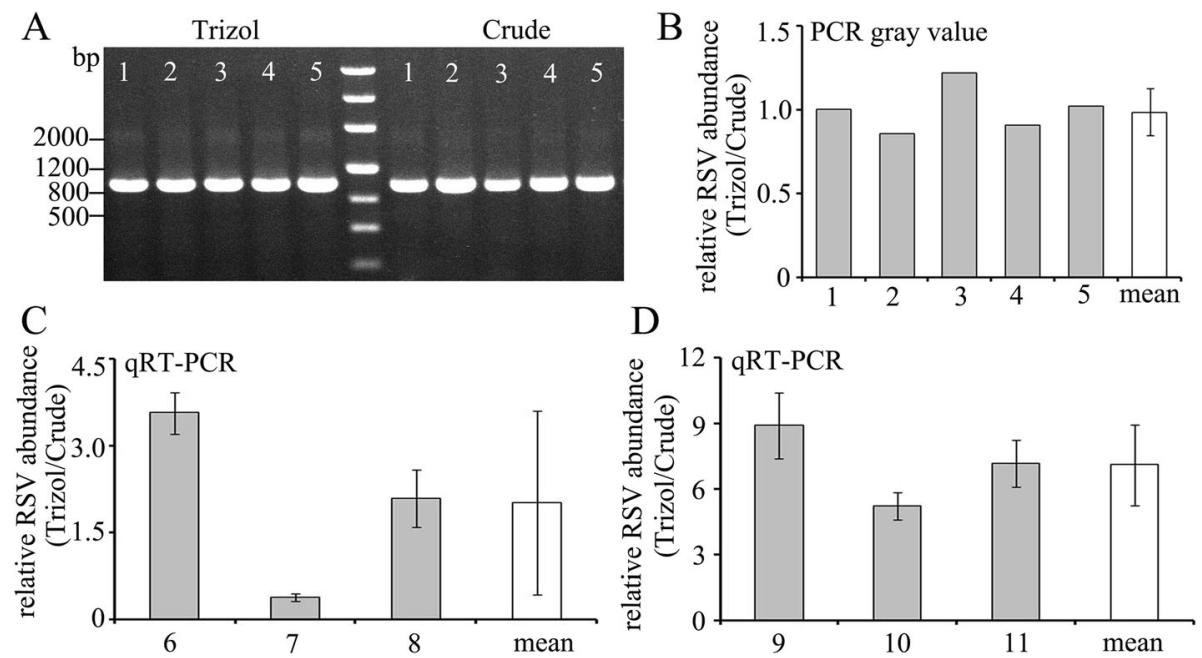

Fig. 6 Comparison of the sensitivity of simplified RT-PCR (Crude) and traditional RT-PCR (Trizol). a PCR products amplified from samples prepared by the two methods. $\mathbf{b}$ Relative RSV abundance evaluated by gray value of PCR products. c Relative RSV abundance evaluated by qRT-PCR in the samples ground by toothpick. d Relative RSV abundance evaluated by qRT-PCR in the samples ground in nitrogen liquid 
sufficient to reliably detect RSV, RBSDV and HiPV in a single SBPH (Figs. 1, 2 and 3). Both RSV and HiPV were detected when cDNA samples were diluted up to $10^{3}$ fold (Fig. 5). These results suggest that the simplified method can be practically applied to virus detection using a single SBPH. The relative abundance of RSV analyzed by qRT-PCR using Trizol-isolated RNA was 7 fold higher than that using RNA in crude extract (Fig. 6d). One explanation is that the Trizol reagent disrupts insect tissues more thoroughly to release RNA from tissues whereas some amounts of RNA may be lost together with tissues during centrifugation in the simplified method.

\section{Conclusions}

A simplified RT-PCR method was developed for detection of RNA virus in a single SBPH by preparing virus RNA in an easy and fast procedure. Our results demonstrated that crude extracts of SBPHs could be used as the template for RT-PCR. The viral RNA prepared by this method was also suitable for duplex RT-PCR and qRT-PCR detection. This protocol reduces the use of costly reagents, shortens the sample processing time, and improves the efficiency of virus detection. As the method is highly simplified and of sufficient sensitivity, it provides a useful tool to the investigation of epidemics of viral diseases in the early stage by enabling easy detection of viruses within a single insect vector.

\section{Additional file}

Additional file 1: Sequencing results of the detected viruses. (DOCX $14 \mathrm{~kb}$ )

Additional file 2: Figure S1. Detected RBSDV in individual field-collected SBPH using the simplified RT-PCR and traditional RT-PCR. (A) PCR products of 96 field-collected SBPH detected by simplified RT-PCR. (B) PCR products of SBPHs detected by traditional RT-PCR. (JPG $1439 \mathrm{~kb}$ )

\section{Abbreviations}

DIBA: Dot immunobinding assay; HiPV: Himetobi P virus;

qRT-PCR: Quantitative real time PCR; RBSDV: Rice black streaked dwarf virus; RSV: Rice stripe virus; RT-PCR: Reverse transcription polymerase chain reaction; SBPH: Small brown planthopper

\section{Acknowledgements}

We thank Dr. Mawsheng Chern of the University of California, Davis, for the advice and help in English editing of the manuscript.

\section{Funding}

This research is supported by the National Natural Science Foundation of China (31471768), the Jiangsu Agriculture Science and Technology Innovation Fund (CX(15)1053), and the Grain High Yield and High Efficiency Technology Innovation Program (2016YFD0300706). These funding bodies had no role in design, collection, and analysis of the study and preparation of the manuscript.

\section{Availability of data and materials}

All data generated or analyzed during this study are included in this published article and its additional files.

\section{Authors' contributions}

QX, YZ and $X J$ participated in experimental design and directed the research. $H L, P Y, X Z$ and QC carried out the experiments and analyzed the data. QX, $\mathrm{HL}$, and $Y Z$ were involved in the writing of the manuscript. All authors read and approved the final manuscript.

\section{Competing interests}

The authors declare that they have no competing interests.

Consent for publication

Not applicable.

Ethics approval and consent to participate

Not applicable.

\section{Publisher's Note}

Springer Nature remains neutral with regard to jurisdictional claims in published maps and institutional affiliations.

\section{Author details}

${ }^{1}$ Institute of Plant Protection; Jiangsu Academy of Agricultural Sciences; Jiangsu Technical Service Center of Diagnosis and Detection for Plant Virus Diseases, Nanjing, Jiangsu, People's Republic of China. ${ }^{2}$ College of Agriculture, Guizhou University, Guiyang, Guizhou, People's Republic of China.

Received: 16 January 2017 Accepted: 16 March 2017

Published online: 03 May 2017

\section{References}

1. Zhang HM, Chen JP, Lei $J$, Adams MJ. Sequence analysis shows that a dwarfing disease on rice, wheat and maize in China is caused by rice black-streaked dwarf virus. Eur J Plant Pathol. 2001;107:563-7.

2. Achon MA, Subira J, Sin E. Seasonal occurrence of Laodelphax striatellus in Spain: Effect on the incidence of Maize rough dwarf virus. Crop Prot. 2013;47:1-5.

3. Deng JH, Li S, Hong J, Ji YH, Zhou YJ. Investigation on subcellular localization of Rice stripe virus in its vector small brown planthopper by electron microscopy. Virol J. 2013;10:310.

4. Di DP, Zhang YL, Yan C, Yan T, Zhang AH, Yang F, et al. First report of Barley yellow striate mosaic virus on wheat in China. Plant Dis. 2014:98:1450-1.

5. Tanno F, Nakatsu A, Toriyama S, Kojima M. Complete nucleotide sequence of Northern cereal mosaic virus and its genome organization. Arch Virol. 2000;145:1373-84

6. Toriyama S, Guy PL, Fuji S, Takahashi M. Characterization of a new picornalike virus, himetobi P virus, in planthoppers. J Gen Virol. 1992;73:1021-3.

7. Huo Y, Liu WW, Zhang FJ, Chen XY, Li L, Liu QF, et al. Transovarial transmission of a plant virus is mediated by vitellogenin of its insect vector. PLoS Pathog. 2014;10:e1003949.

8. Wei TY, Yang JG, Liao FR, Gao FL, Lu LM, Zhang XT, et al. Genetic diversity and population structure of rice stripe virus in China. J Gen Virol. 2009;90:1025-34.

9. Wang HD, Chen JP, Wang AG, Jiang XH, Adams MJ. Studies on the epidemiology and yield losses from rice black-streaked dwarf disease in a recent epidemic in Zhejiang province, China. Plant Pathol. 2009;58:815-25.

10. Zhang SX, Li L, Wang XF, Zhou GH. Transmission of Rice stripe virus acquired from frozen infected leaves by the small brown planthopper (Laodelphax striatellus Fallen). J Virol Methods. 2007;146:359-62.

11. Li L, Li HW, Dong HB, Wang XF, Zhou GH. Transmission by Laodelphax striatellus Fallen of Rice black-streaked dwarf virus from frozen infected rice leaves to healthy plants of rice and maize. J Phytopathol. 2011;159:1-5.

12. Hunter WB, Patte $C P$, Sinisterra $X H$, Achor DS, Funk CJ, Polston JE. Discovering new insect viruses: Whitefly iridovirus (Homoptera : Aleyrodidae : Bemisia tabaci). J Invertebr Pathol. 2001:78:220-5.

13. Wu JX, Ni YQ, Liu H, Rao LX, Zhou YJ, Zhou XP. Development and use of three monoclonal antibodies for the detection of rice black-streaked dwarf virus in field plants and planthopper vectors. Virol J. 2013;10:114.

14. Wu JX, Ni YQ, Liu H, Ding M, Zhou XP. Monoclonal antibody-based serological assays and immunocapture-RT-PCR for detecting Rice dwarf virus in field rice plants and leafhopper vectors. J Virol Methods. 2014;195:134-40.

15. Zhang $X$, Wang XF, Zhou GH. A one-step real time RT-PCR assay for quantifying rice stripe virus in rice and in the small brown planthopper (Laodelphax striatellus fallen). J Virol Methods. 2008;151:181-7.

16. Zhang X, Zhou G, Wang X. Detection of wheat dwarf virus (WDV) in wheat and vector leafhopper (Psammotettix alienus Dahlb.) by real-time PCR. J Virol Methods. 2010;169:416-9. 
17. Cai L, Ma XZ, Kang L, Deng KJ, Zhao SY, Li CB. Detecting Rice stripe virus (RSV) in the small brown planthopper (Laodelphax striatellus) with high specificity by RT-PCR. J Virol Methods. 2003;112:115-20.

18. Cho SY, Jeong RD, Yoon YN, Lee SH, Shin DB, Kang HW, et al. One-step multiplex reverse transcription-polymerase chain reaction for the simultaneous detection of three rice viruses. J Virol Methods. 2013;193:674-8.

19. Xu QF, Ni HP, Zhang JF, Lan Y, Ren CM, Zhou YJ. Whole-genome expression analysis of Rice black-streaked dwarf virus in different plant hosts and small brown planthopper. Gene. 2015;572:169-74.

20. Suzuki Y, Toriyama S, Matsuda I, Kojima M. Detection of a picorna-like virus, himetobi-P virus, in organs and tissues of Laodelphax Striatellus by immunogold labeling and enzyme linked immunosorbent assay. J Invertebr Pathol. 1993;62:99-104.

21. Xu Y, Huang LZ, Wang ZC, Fu S, Che J, Qian YJ, et al. Identification of Himetobi $\mathrm{P}$ virus in the small brown planthopper by deep sequencing and assembly of virus-derived small interfering RNAs. Virus Res. 2014;179:235-40.

22. Hogenhout $\mathrm{SA}$, Ammar ED, Whitfield AE, Redinbaugh MG. Insect vector interactions with persistently transmitted viruses. Annu Rev Phytopathol. 2008;46:327-59.

23. Li S, Wang $X$, Xu JX, Ji YH, Zhou YJ. A simplified method for simultaneous detection of Rice stripe virus and Rice black-streaked dwarf virus in insect vector. J Virol Methods. 2015;211:32-5.

24. Zhou T, Du L, Fan Y, Zhou Y. Reverse transcription loop-mediated isothermal amplification of RNA for sensitive and rapid detection of southern rice black-streaked dwarf virus. J Virol Methods. 2012;180:91-5.

25. Ridgeway JA, Timm AE. Comparison of RNA isolation methods from insect larvae. J Insect Sci. 2014;14:268.

26. Sambrook JFE, Maniatis T. Molecular cloning: a laboratory manual. 2nd ed. New York: Cold Spring Harbor Laboratory Press; 1989

27. Suehiro N, Matsuda K, Okuda S, Natsuaki T. A simplified method for obtaining plant viral RNA for RT-PCR. J Virol Methods. 2005;125:67-73.

\section{Submit your next manuscript to BioMed Central and we will help you at every step:}

- We accept pre-submission inquiries

- Our selector tool helps you to find the most relevant journal

- We provide round the clock customer support

- Convenient online submission

- Thorough peer review

- Inclusion in PubMed and all major indexing services

- Maximum visibility for your research

Submit your manuscript at www.biomedcentral.com/submit

Biomed Central 